\title{
Reusability of face-masks: Facing the pandemic
}

\author{
Aligina Anvitha Sudheshna and Meenu Srivastava
}

Received: 14.02.2020; Accepted: 19.05.2020

See end of the paper for authors' affiliations Aligina Anvitha Sudheshna Department of Textiles and Apparel Designing, College of Community and Applied Sciences, Maharana Pratap University of Agriculture and Technology, Udaipur (Rajasthan) India

Email : anvithasudheshna@ gmail.com
ABSTRACT : An unhealthy person can act as carrier to transmit the pathogens like virus, bacteria through respiration, if proper face covering in the form of face mask is not used by them to block the spreading of tiny droplets. Studies show that an infectious aerosol remains in the air for more than 6 hours after release. Respiration via inhalation or exhalation accompanied with sneezing or coughing by infected people gathered in group at society or park or any other public places is one of the common modes of transmission of this pandemic due to COVID19. Understanding the importance of taking adequate preventive actions like frequent cleaning of hands, using face masks that provide concealment to nose and mouth without any gap for air leakage can assist in protecting the individual, family and community at large from this deadly virus. This review article highlights various facets related to face mask and how they act as barrier against such harmful pathogens.

KEY WORDS: Face mask, COVID 19 pandemic, Properties, Function, Material, Efficiency

- HOW TO CITE THIS PAPER : Sudheshna, Aligina Anvitha and Srivastava, Meenu (2020). Reusability of face-masks: Facing the pandemic. Asian J. Home Sci., 15 (1) : 149-154, DOI: 10.15740/HAS/AJHS/ 15.1/149-154. Copyright@ 2020: Hind Agri-Horticultural Society. 